\title{
CORPORATE GOVERNANCE, TRANSPARANCY AND STOCK RETURN SYNCHRONICITY
}

\author{
Adrian Christianto \\ Fakultas Bisnis dan Ekonomika, Universitas Surabaya, Indonesia \\ Werner R. Murhadi \\ Fakultas Bisnis dan Ekonomika, Universitas Surabaya, Indonesia \\ werner@staff.ubaya.ac.id \\ Liliana Inggrit W \\ Fakultas Bisnis dan Ekonomika, Universitas Surabaya, Indonesia \\ liliana@staff.ubaya.ac.id
}

\begin{abstract}
This study aims to analyze the effect of corporate governance on transparency as measured by stock return synchronicity. The variables used are board size (commissioner), big4 audit, institutional ownership, market to book, the volatility of firm fundamentals, leverage, and firm size. This study uses a quantitative approach with multiple linear analysis models. This study uses a sample of non-financial business entities listed on the Indonesia Stock Exchange (BEI). The number of samples used in this study was 198 observations. The results showed that the variable board size (commissioner), institutional ownership, and leverage had a positive effect on transparency, and the implied volatility of the firm hurt transparency. Other variables such as big4 audit, market to book ratio, and firm size do not affect transparency.

Keywords: transparency, corporate governance, stock return synchronicity
\end{abstract}

\section{INTRODUCTION}

Corporate governance plays an essential role in the company and will impact the company's finances. Corporate governance can be used as a strength within the company to compete in the current situation. Companies that have good governance will be more transparent compared to companies that do not have proper management.

In this study, the transparency of the company will be measure using stock return synchronicity. Morck et al. (2000) state that the stock return will move along with market returns. Khandaker (2011) explains that Stock return synchronicity shows the stock market's tendency to move in the same direction for some time to come. The market will be synchronized if, in general, individual share prices move together. Sometimes, the concepts of beta and synchronicity become difficult to separate. This concept is because both ideas show the same relationship between a 
company's asset return and market return. However, there are fundamental differences between these two concepts. Synchronicity explained how the market return explains the performance of a company's assets, while beta reflects the systematic risk of a company's assets, which is usually measured by the contribution of the risk of an asset to the portfolio (Farooq \& ElBannan, 2019). In plain language, beta is the contribution of an asset to the market, whereas synchronicity contributes the market to an asset. Jin and Myers (2006) argue that stock return synchronicity can be interpreted as a measure of corporate transparency because it shows how much the market index reflects the return of a company's stock. Khandaker and Heaney (2008) stated that countries with high inflation, corruption, and bad corporate governance have higher stock market synchronicity in developing countries.

According to Morck et al. (2000), there are two models for looking at stock return synchronicity. The first model includes the market-wide movement in the price of shares of individual companies for a certain period, known as the Classical Synchronicity measure. Furthermore, the second model is the market model using R Square measurement, which includes specific stock price movements reflected in overall stock price movements. Market-wide synchronicity described where shares in the stock market move together at a time. While firm-level synchronicity is defined, the price of a stock moves along with the market return at a time. This research focuses on firm-level synchronicity, where trading shares based on the amount of company-specific information will make stock prices contain company-specific information and reduce synchronization of stock prices (Durnev et al., 2003, Tee, 2017). The stock return synchronicity concept assumes that stock prices and stock returns explain two information; first, the company information and market information. When the stock returns can be defined more by the market information, the stock returns have high synchronicity. According to Gul et al. (2010), when synchronicity is high, the company information obtained from the company's stock returns is low, so that the company's transparency is low. Second, company information can explain stock returns, and the shares will show idiosyncratic dependencies. Idiosyncratic is a risk that reflects specific information about the company, and the risk will change according to changes in company-related information. Also, the company's stock price would be reflected in the company's stock price that can be used to measure the level of transparency of the company.

Gyamfi et al. (2015) measure corporate governance towards transparency. The Ghana study found that board size, market to book ratio, implied volatility of firm, and audit quality positively affected synchronicity, while CEO duality harmed synchronicity. Tas and Tan's research (2016) found that board size and CEO duality hurt the synchronicity and volatility of firm fundamentals, and the market to book ratio had a positive effect on synchronicity. While other research by An and Zhang (2013) provides the results of institutional ownership, size, and volatility of firm fundamentals positively affect synchronicity, While the leverage hurts synchronicity. Research by Gul et al. (2009), the results are substantial shareholders, and large 
shareholders' government positively affects synchronicity while audit quality and foreign investment hurt synchronicity.

According to the research of Gyamfi et al. (2015), board size (commissioner) has a significant positive effect on synchronicity. This result indicates that when the board size (commissioner) has a large scale, it will note with high synchronicity where the company information reflected is smaller than market information. When more market information is displayed, it will synchronize with the market to make company transparency low. Low transparency due to the large board size (commissioners) causes the board of commissioners to find it challenging to coordinate and resolve problems in the company. Also, there is the issue of 'free-rider' in which not all boards of commissioners supervise the company's management (Lipton and Lorsch, 1992; Jensen, 1993). According to Tas and Tan (2016), the board size (commissioner) is not significant to transparency. According to Adam and Mehran (2003), board size (commissioners), which have a large scale, can effectively carry out supervision to increase company transparency and low synchronicity. Corporate transparency increases because more company information reflected in the market compared to market information.

The big4 audit has no significant effect on synchronicity (Gyamfi et al., 2015). According to Gul et al. (2009), big4 audit has a significant negative impact on synchronicity. Companies that use big4 audit have profound synchronicity because the company information is more reflected than market information to make company transparency high. Excellent company transparency because when companies use big4 auditors, there will be a lot of company information displayed on financial reports, and the quality of audits conducted is also better than not-big4 auditors (Mitton, 2002; Fernandes and Ferreira, 2008; Kim and Shi, 2009). Proper audit quality is also due to the influence of the auditor's reputation effect, where large audit companies have more incentives used to minimize errors in conducting audits (Angelo, 1981).

According to Gyamfi et al. (2015), institutional ownership does not significantly affect synchronicity. After all, institutional investors enter the capital market to place excess funds owned but not used to execute projects with a positive NPV because institutional investors may not be interested in the company's activities (Haniffa and Cooke, 2002). According to An and Zhang (2013), institutional ownership has a significant positive effect on synchronicity. This result shows that when institutional ownership gets bigger, it will cause high synchronicity. The company's shares are more synchronous with the market because the company information reflected in the market is smaller than the market information, which makes the company's transparency low. Low company transparency due to transient institution investors is more focused on getting maximum profit in the short term. Temporary institutions are more focused on short-term investments because investors cannot get company-specific information relevant in the long run. Investors would prefer to sell their shares rather than spend more to discipline managers when the 
company has poor performance (Bushee, 1998; Piotroski and Roulstone, 2004). According to Le et al. (2006), Langnan et al. (2007), and Ramzi (2008), the presence of institutional ownership in the list of company shareholders will affect the level of transparency of the company. Institutional owners will conduct strict supervision to reduce the information asymmetry that occurs in the company to be more transparent and low synchronicity. Profound synchronicity is because company information is more reflected than market information, making companies have high transparency.

The market to book ratio has a significant positive effect on synchronicity (Gyamfi et al., 2015; An and Zhang, 2013). This statement shows that when a company has high growth potential, it will cause high synchronicity because its information reflected in the market is less than market information, so the company's transparency is low. The low transparency is because companies with high growth potential are usually newly listed and not matured firms that have long listed. High competition levels will follow recently registered companies with higher growth, so companies do not want to disclose company-specific information. As a matured firm and has long been listed on the stock exchange, the company has profound synchronicity because it will be more transparent about the company's information. According to Tas and Tan (2016) and Gul et al. (2009), the market to book ratio has a significant negative effect on synchronicity. When a company has high growth potential, the company will give a signal in the market more openly about company information so that investors can find out the company's ability to create excellent company transparency and profound synchronicity (Hasan et al., 2014). Little synchronicity is because company information is more reflected than market information, making companies have high transparency.

According to Gyamfi et al. (2015), the firm's implied volatility has a significant positive effect on synchronicity. The change in income varies due to competition between companies (Li et al., 2003). This high level of competition causes companies to be less willing to be open to the company's information. Tas and Tan (2016) implied volatility of the firm has a significant negative effect on synchronicity. When changes in income are substantial, it will cause uncertainty of income at the company. The risk of revenue requires companies to be more open to existing information to be transparent. Important company transparency causes low synchronicity because company information is reflected more than market information. According to Gul et al. (2009), the firm's implied volatility does not significantly influence synchronicity.

This study will use seven variables consisting of 3 independent variables: proxies from GCG, namely board size (commissioner), big4audit, institutional ownership, and other independent variables are market to book ratio and fundamental volatility of the firm. The control variables used are leverage and firm size. 


\section{RESEARCH METHODS}

This study uses a time sample by entering all non-financial sector companies listed on the IDX for the 2012-2016 periods. One hundred ninety-eight companies meet the criteria and become the target population.

According to Tas and Tan (2016), corporate governance is crucial for developing countries where investor security is still relatively low. The existence of corporate governance can reduce information asymmetry in the company. Companies with good quality governance will make the company more open about the company's information (Beeks and Brown, 2005). In some literature, stock return synchronicity is used to understand the company's openness (transparency). Stock return synchronicity can be explained where the stock market tends to move in the same direction in a period (Khandaker, 2011). The market will be more synchronous when the movement of individual stock prices changes with market share prices. Through the movement of the share price, the condition and performance of the company had reflected. According to Jin and Myres (2006), stock return synchronicity can describe the company's transparency because the movement of the company's shares can reflect information about the company.

In this study, company transparency is measured using stock return synchronicity with the formula:

$$
S Y N C H_{i t}=\log \left(\frac{R^{2}}{1-R^{2}}\right)_{i t}
$$

To measure $\mathrm{R}^{\wedge} 2$ ( $\mathrm{R}$ square), a market model method is needed

$$
R_{i, t}=\propto_{i}+\beta_{1} \times R_{m, t}+\beta_{2} \times R_{m, t-1}+\varepsilon_{i, t}
$$

Later a linear regression will be performed between the company's stock returns, market returns, and market returns $t-1$ to get the value $\mathrm{R}^{\wedge} 2$ (R square) using the Eviews program. Data for calculation of company stock returns and market returns uses daily data. If the company's synchronicity is high, it will cause the company's transparency to be low (Gul et al., 2010). This low transparency is because market information is reflected more than company information.

The board of commissioners (BS) is the number of members of the board of commissioners, both from internal and external companies. Beasley et al. (2005) classify the most significant international accounting firm with high audit quality called the big4 audit firm (BIG4). The accounting firms included in the big4 audit firm is Price Waterhouse Coopers, Ernest and Young, Deloitte and Touche, and KPMG. The company has the best audit capabilities compared to accounting firms that did not include in the big4 audit firm. An accountant company with a good reputation will provide many incentives for auditors to minimize the mistakes that occur. This effect is referred to as auditor reputation effects (Deangelo, 1981). Measurements made by giving the number 1 if the company was audited by one of the big 4 auditors and the number 0 if vice versa. Institutional Ownership (IO) is share ownership by a legal entity. The existence of institutional ownership in a company 
will encourage increased oversight of company management. Supervision carried out by institutional investors is needed to reduce information asymmetry between management and stakeholders. Control conducted will impact the transparency of a company (Haniffa and Cooke, 2002). Institutional ownership is measured by the percentage of institutional shareholders of the total shareholders.

Market to book ratio (MB) is a ratio used to measure a company's growth potential. When a company has high growth potential, the company will give signals in the market more openly about company information so that investors can know the company's ability (Hasan et al., 2014). Market to book ratio calculated by dividing market capitalization by total equity. Implied volatility of firm (FF) is to see changes in income received by the company. The uncertainty of a company's revenue stream is measured by the risk (standard deviation) of return on assets (ROA) calculated for five years.

Leverage (LEV) is a ratio to measure the extent to which a company's assets can be financed by debt. It also can measure the company's ability to fulfill its responsibilities (Kasmir, 2008). When companies often use debt, it can be expected that a company will become more transparent because creditors will conduct supervision to ensure that the company can pay its obligations-leverage calculated with a debt ratio. Firm size is a grouping of companies in large, medium, and small groups. The scale used to measure companies included in large, medium, and small groups are to look at the company's total assets (Suwito and Herawaty, 2005). The firm's size (FS) can be measured using the natural logarithm formula for total assets.

\section{RESULTS\&DISCUSSION}

The data used is panel data, and after conducting the Chow and Hausmman test, the model that will apply for analysis is the fixed effect model.

Table 1

Data Processing Results

\begin{tabular}{cccc}
\hline Variable & Coefficient & t-Statistic & $\begin{array}{c}\text { Hypothesis (to } \\
\text { transparency) }\end{array}$ \\
\hline BS & 0.035935 & $1.706^{* * *}$ & Negative \\
BIG4 & 0.22629 & 1.193939 & Positive \\
IO & -0.306846 & $-2.5546 * *$ & Positive \\
MB & 0.001227 & 1.314704 & Positive \\
FF & 0.006831 & $1.911^{* * *}$ & Positive \\
LEV & -0.298251 & $-3.68845^{*}$ & Positive \\
FS & -0.103508 & -1.476173 & Positive \\
Adjusted R-squared & & 0.819096 \\
F-statistic & & 22.95097 \\
Prob(F-statistic) & & 0.000000 \\
\hline
\end{tabular}

Journal of Entrepreneurship \& BusinessVol. 2 No. 1 
From table 1, it can be seen that the effect of board size (commissioners) on transparency is negative and significant. A large board size causes the company's transparency to decrease due to the large size of the board of commissioners, which makes it difficult for the board of commissioners to coordinate and resolve problems that occur in the company. Also, there is the issue of 'free-rider' in which not all boards of commissioners supervise the company's management (Lipton and Lorsch, 1992; Jensen, 1993). These results are supported by Gyamfi et al. (2015), which states a negative relationship between board size (commissioners) and transparency.

Table 1 shows that the big4 audit and transparency variables are negative but not significant. The negative relationship indicates that when a company uses one of the big4 auditors, its transparency decreases. According to Francis \& Yu (2009), it is likely due to the low level of competition faced by the big 4 KAP, which makes the audit quality produced by the big 4 KAP decline. Market dependence on the superiority of KAP big 4 makes KAP, not the big four challenging to compete. With the condition of having many clients, making KAP big four feel that they are in a safe area and tend to pay less attention to the audit quality so that it allows a decrease in audit quality. However, the results of this study are not significant; this is supported by research by Gyamfi et al. (2015), who found no significant negative relationship to transparency. That is because whether using the big four or not big-4 audit services, companies going public should disclose company information through financial reports that have been prepared by financial accounting standards and have been audited by public accountants registered with the Financial Services Authority (OJK). The discloses should be done so that investors can know about the company's state so that investors can consider it in making investment decisions (Kusumawati, 2013 and Sebayang, 2014).

Based on table 1, the relationship between institutional ownership and transparency is positive and significant. So, according to Le et al. (2006), Langnan et al. (2007), and Ramzi (2008), the presence of institutional ownership in the list of company shareholders will affect the level of transparency of the company. Institutional owners will conduct strict supervision to reduce the information asymmetry that occurs in the company to be more transparent and low synchronicity. Profound synchronicity is because company information is more reflected than market information, making companies have high transparency.

From table 1, the effect of the market to book on transparency is negative but not significant. The negative relationship shows that when a company has high growth potential, it will cause high synchronicity because its information reflected in the market is less than market information, so the company's transparency is low. The low transparency is because companies with high growth potential are usually newly listed companies and not matured firms that have long been listed. High levels of competition will follow high growth in newly listed companies, so companies do not want to disclose company-specific information. However, the results of this study are not significant. That is because both companies with high or low growth 
opportunities have the same motivation to attract investors' attention by disclosing company information so that investors can get information about the company in full, and investors can get the same information (Indriani, 2013).

The fundamental volatility firm variable has a significant negative effect on transparency. This volatility is supported by Gyamfi et al. (2015); there is a change in income that varies due to the level of competition between companies ( $\mathrm{Li}$ et al., 2003). This high level of competition causes companies to be less willing to be open to the company's information. Low company transparency creates high synchronicity because market information is reflected more than company information. Leverage variables have a significant positive relationship with transparency. This positive relationship supported by An and Zhang (2013), when the company's leverage is increasing, the agency conflict in the company will be reduced because managers will disclose information to lenders, so that company transparency increases and synchronicity is low. The low synchronicity is because company information is reflected more in the market than in market information. (Jensen and Meckling, 1976) This low synchronicity means that the relationship between firm size and transparency is positive but not significant. This positive relationship indicates that companies with a larger size of stock prices can better describe the state of the market because large companies are a significant part of the companies included in the market and industry indexes and have various business segments in multiple industries (Chan and Hameed, 2006). Also, companies with a larger size will be more open in disclosing existing information, so that company transparency is high (Firth, 1979). it is indicated that more company information is displayed in the market than market information to create low synchronicity and high company transparency. However, this study's results are not significant; this is supported by research by Tas and Tan (2016), who found an insignificant positive relationship between firm size and transparency. That is because both large and small companies, when going public they will be in the public spotlight and under the supervision of government agencies or stock exchanges so that they will carry out excellent or minimum corporate governance following the rules of the Financial Services Authority (OJK). The implementation of good corporate governance will minimize information asymmetry within the company to be more transparent (Sundari et al., 2015).

\section{CONCLUSION}

The board size variable (commissioner) in this study has a negative and significant relationship to transparency. The large size of the commissioners' board makes it difficult for the board of commissioners to coordinate and resolve problems that occur in the company. Also, there is the issue of 'free-rider' where not all boards of commissioners supervise the company's management. The institutional ownership variable in this study has a positive and significant relationship to transparency. The presence of institutional ownership on the company's shareholder list will affect the company's transparency. The fundamental volatility firm variable in this study has a 
significant negative relationship with transparency. The change in income varies due to the level of competition between companies. This high level of competition causes companies to be less willing to be open to the company's information. The leverage variable in this study has a significant positive relationship with transparency. When the company's leverage is increasing, the company's agency conflict will be reduced because the managers will disclose the information available to the lender so that the company's transparency increases and makes synchronicity low. Simultaneously, the big4 audit variable, market to book, and firm size do not affect transparency.

\section{REFERENCES}

Adam, R. B., \& Mehran, H. (2003). Is Corporate Governance Different for Bank Holding Companies? Economic Policy Review - Federal Reserve Bank of New York, Vol 9(1): 123- 142.

Beasley, M.S., Clune, R. , \& Hermanson, D. R. (2005). Enterprise Risk Management: An Empirical Analysis of Factors Associated with the Extent of Implementation. Journal of Accounting \& Public Policy, Vol 24(6):521-531.

DeAngelo, L.E. 1981. Auditor Size and Audit Quality. Journal of Accounting \& Economics, Vol 3(3):183-199.

Farooq, O. \& El Bannan, M.A. (2019), Stock price synchronicity and dividend policy: evidence from an emerging market. Accounting Research Journal, Vol. 32(4): 627-641. https://doi.org/10.1108/ARJ-02-2018-0036

Fernandes, N., \& Ferreira, M. (2008). Does international cross-listing improve the information environment? Journal of Financial Economics, Vol.88(2): 216-244.

Francis, J.R., \& Yu, M.D. 2009. Big 4 Office Size and Audit Quality.The Accounting Review, Vol84(5): 1521-1552.

Gul, F.A, Jeong-Bon Kim, \& Annie A.Qiu, 2010, Ownership Concentration, Foreign Shareholder, Audit Quality, dan Stock Price Synchronicity: Evidence from China, Journal of Financial Economics, Vol.95(3):425-442.

Heng An dan Ting Zhang, 2013, Stock Price Synchronicity, Crash Risk, dan Institutional Investor, Journal of Corporate Finance, Vol.21:1-15.

Indriani, Erna Wati, 2013, Faktor-Faktor yang Mempengaruhi Luas Pengungkapan Sukarela dan Implikasinya terhadap Asimetri Informasi, Skripsi, Fakultas Ekonomi, Universitas Negeri Semarang: Semarang.

Jensen, M.C., 1993, The modern industrial revolution, exit, and the failure of internal control systems, Journal of Finance, Vol.48(3):831-880.

Jin, L., \& Myers, S., 2006. 2 R around the World: New Theory and Tests, Journal of Financial Economics, Vol. 79(2): 257-292

Khandaker, S. 2011. R Square Measure of Stock Synchronicity. International Review of Business Research Paper, Vol 7(1):165-175.

Morck, R., Yeung, B., \& Yu, W. 2000. The Information Content of Stock Markets: Why Do Emerging Markets Have Synchronous Stock Price Movements?, Journal of Financial Economics Vol. 58(1):215-260. 
Ntow-Gyamfi, Matthew, G.A.Bokpin, dan A.Gamegah, 2015, Corporate Governance and Transparancy: Evidence from Return Synchronicity, Journal of Financial Economic Policy, Vol.7(2): 157-179.

Piotroski, Joseph D. dan Barren T. Roulstone, 2004, The Influence of Analysts, Institutional Investors, and Insiders on the Incorporation of Market, Industry, and Firm-Specific Information into Stock Prices, The Accounting Review, Vol.79(4): 1119-1151.

Ramzi, B. 2008. The influence of institutional investors on opportunistic earnings management, International Journal of Accounting, Auditing and Performance Evaluation, Vol. 5(1): 89-106.

Sebayang, Esynasali Violetta, 2014, Analisis Faktor yang MempengaruhiAudit Delay, Skripsi, Fakultas Ekonomika dan Bisnis Universitas Diponegoro: Semarang.

Tas, Oktay dan Selin Duz Tan, 2016, Corporate Governance, Foreign Ownership, dan Stock Price Synchronicity: Evidence from Borsa Istanbul, Journal of Economic, Finance and Accounting, Vol 3(2):156-165.

Tee, C.M. (2017), Political connections, institutional investors monitoring and stock price synchronicity: Evidence from Malaysian firms, Managerial Finance, Vol. 43(11):1236-1253. https://doi.org/10.1108/MF-03-2017-0099 